\title{
DISTRIBUTION CHARACTERISTICS AND CONTROL FACTORS OF HYDROGEN SULFIDE IN XISHAN COAL MINE OF SOUTHERN MARGIN OF JUNGGAR BASIN IN CHINA
}

\author{
Qigen $\mathrm{DENG}^{1,2,3 *}$, Feng $\mathrm{WU}^{4}$, Xifa $\mathrm{WU}^{1}$, Yingnan $\mathrm{WANG}^{1}$ and Mingju LIU ${ }^{1,2}$ \\ ${ }^{1}$ State Key Laboratory Cultivation Base for Gas Geology and Gas Control (Henan Polytechnic University), \\ Jiaozuo 454003, China \\ ${ }^{2}$ School of Safety Science and Engineering, Henan Polytechnic University, Jiaozuo 454003, China \\ ${ }^{3}$ Collaborative Innovation Center of Coal Safety Production of Henan Province, Jiaozuo 454003, China \\ ${ }^{4}$ English Department of ChongRen Normal School, Fuzhou 344200, China \\ *Corresponding author: dengqigen@hpu.edu.cn
}

(Received May 2018; accepted July 201)

Key words: southern margin of Junggar basin, hydrogen sulfide, distribution characteristics, control factors

\begin{abstract}
The regional structure of Xishan coal mine, located in the binding site of southern margin of Junggar basin and northern mountain Tianshan, belongs to the foothill fault-fold structural belt of southern margin of Junggar Basin. Most the coal seams which were formed by continental facies are in the range of medium-extra low sulfur and part of the coal seams belong to high sulfur coal. The hydrogen sulfide in coal seam concentrate anomaly and distribute very unevenly, with the maximum value of $\mathrm{H}_{2} \mathrm{~S}$ up to $2.11 \%$. The gas composition in coal bed mainly are $\mathrm{N}_{2}$ and $\mathrm{CH}_{4}$, components $\mathrm{H}_{2} \mathrm{~S}, \mathrm{CO}_{2}, \mathrm{C}_{2} \mathrm{H}_{6}$, $\mathrm{C}_{3} \mathrm{H}_{8}$ and another heavy hydrocarbon. The mirror reflectance of coal is generally between $0.5 \%$ to $0.7 \%$. The abundant source rocks are the strong material basis for the formation of $\mathrm{H}_{2} \mathrm{~S}$. The pore structure of coalbed belongs to the fracture-pore type. The medium and better reservoir have a wide range of distribution. The proportion of roof microclastic rocks and floor microclastic rocks of coal seam is up to $75 \%$ and $87 \%$ respectively. These factors are conducive to the enrichment of $\mathrm{H}_{2} \mathrm{~S}$. The thick aquifer formed in the sag basement, under the control of hydrodynamic block gas, provides a huge space of occurrence and migration for groundwater and $\mathrm{H}_{2} \mathrm{~S}$. Along the runoff direction, the salinity, $\mathrm{pH}$ value and $\mathrm{H}_{2} \mathrm{~S}$ content in regional groundwater gradually increase. The water is rich of sulfate ion, reflecting a closed well of regional deep confined water. In sufficient organic matter and reducing environment, the hydrogen sulfide will come into being in the role of BSR or TSR.
\end{abstract}

Palabras clave: margen sur de la cuenca Junggar, sulfuro de hidrógeno, distribución de características, factores de control

\section{RESUMEN}

La estructura regional de la mina de carbón de Xishan, localizada en la unión de margen sur de la cuenca de Janggar y el norte de la montaña Tianshan, pertenece a las estribaciones de fallas y plegamientos del cinturón estructural del margen sur de dicha cuenca. La mayoría de las vetas de carbón, que se formaron por facies continentales, están en el rango medio y extra bajo en cuanto a contenido de sulfuro y otras más en el rango 
elevado de azufre. El sulfuro de hidrógeno en las vetas de carbón se distribuye de manera anómala y desigual, con valor máximo de $\mathrm{H} 2 \mathrm{~S}$ de hasta $2.11 \%$. Los gases en la cama de carbón son principalmente $\mathrm{N} 2$ y CH4, y otros componentes como $\mathrm{H} 2 \mathrm{~S}, \mathrm{CO} 2, \mathrm{C} 2 \mathrm{H} 6$, $\mathrm{C} 3 \mathrm{H} 8$ y algunos hidrocarburos pesados. La reflectancia de espejo del carbón está generalmente entre 0.5 y $0.7 \%$. La abundante fuente de rocas es la fuerte base material para la formación de H2S. La estructura de poro de la cama de carbón es del tipo fractura de poro. El reservorio medio y mejor tiene un amplio rango de distribución. La proporción de rocas microclásticas en el techo y en el piso de la veta de carbón es de 75 y 78 \%, respectivamente. Estos factores son conducivos al enriquecimiento de H2S. El acuífero grueso formado en la caída del basamento, bajo el control hidrodinámico del bloque de gas, proporciona un gran espacio para la ocurrencia y migración de agua subterránea y H2S. A lo largo de dirección de la corriente, la salinidad, el valor del pH y el contenido de $\mathrm{H} 2 \mathrm{~S}$ se incrementan gradualmente en el agua subterránea regional. El agua es rica en el ión sulfato, reflejando un pozo regional cerrado y profundo de agua confinada. Con suficiente materia orgánica y ambiente reductor, el sulfuro de hidrógeno se formará y tendrá el rol de BSR o TSR (por sus siglas en inglés).

\section{GEOLOGICAL BACKGROUND}

Xishan coal mine is located in the binding site of southern margin of Junggar basin and northern Tianshan (the middle of southern margin of Junggar basin). Its regional structure belongs to the foothill fault-fold structural belt of southern margin of Junggar basin (Zhidong et al. 2005, Tianbao et al. 2013, Zhongxian et al. 2000, Razali et al. 2017). The piedmont deep in southern margin of Junggar basin divided into four secondary units, namely, Shihezi sag, the foothill fault-fold structural belt of the west of Urumqi, the foothill fault-fold structural belt of the east of Urumqi and Sikeshu sag (Zhongxian et al. 2000, Xinwei et al. 2005, Shihu et al. 2007, Chengzao et al. 2003, Razali et al. 2017, Rafiq et al. 2018). Xishan coal mine is located in the foothill fault-fold structural belt (the thrust nappe structural belt) of Yilinheibiergen Mountain, it's in the west of Urumqi. Its tectonic distribution is consistent with the direction of the Tianshan fold belt, which is made of a series of nearly EW-NE syncline anticline and thrust faults. The regional geological outline is shown in Fig. 1.

Regional faults mainly include Xishan fault $\left(F_{7}\right)$, Wangjiagou fault group $\left(F_{8}\right)$ and Jiujiawan fault group $\left(F_{9}\right)$, shown in Fig.1. The most geomorphic evidence of the Xishan fault in Xishan coal mine is the cliff monoclinic mountain, formed by the broken gravel platform in the Middle pleistocene. In the hanging wall (north) of fault, a monoclinic structure (Xishan uplift) is steep in the south and flat in the north. A tilting fault block low mountain was formed in geomorphic. On the footwall (south) of fault, the gentle north-dipping gobi gravel plain is developed. The fall head of two fault is over $100 \mathrm{~m}$. The geologic

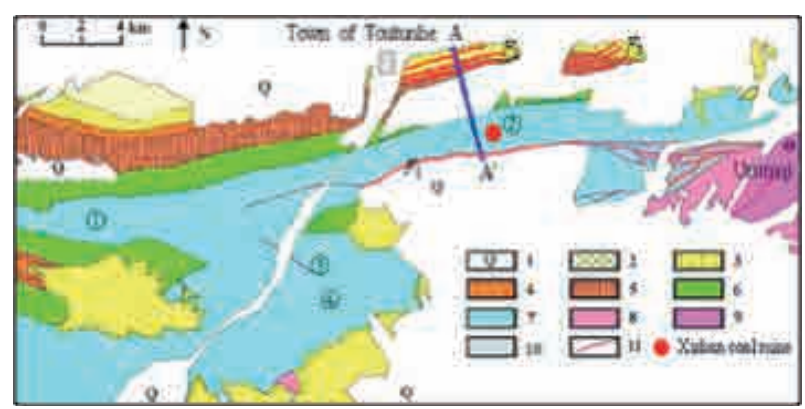

1, Quaternary. 2, The upper segment of Changji river group. 3, The lower-middle segment of Changji river group. 4, Qianshan formation. 5, Upper Cretaceous and the lower tertiary. 6, Tugulu group of lower Cretaceous. 7, Jurassic system. 8, Triassic system. 9, Permian System. 10, Pre-permian system. 11, Fault. (1) Kalaza anticline. (1) Xishan anticline. (3) North Xiaoquzi anticline. (4) South Xiaoquzi anticline

Fig. 1. Regional geological outline

cross sections of Xishan fault and Wangjiagou fault are shown in Fig. 2.

The profile of mining area is shown in Fig. 3. The main coal-bearing stratum are the Jurassic low Xishanyao formation $\left(\mathrm{J}_{2} x^{1}\right)$, which has total of 22 to 34 coal-bearing layers with a total thickness of

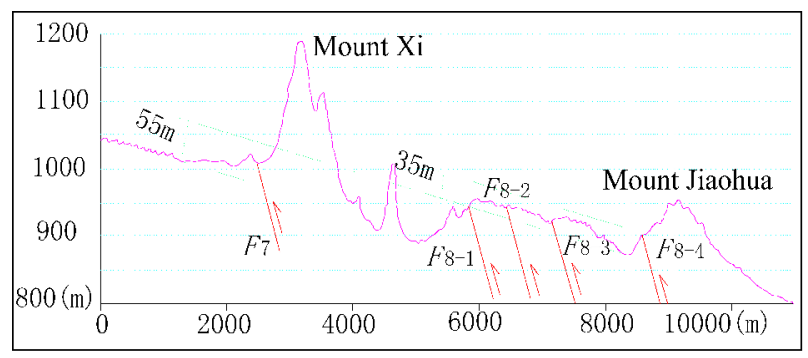

Fig. 2. Geologic cross sections of Xishan and Wangjiagou fault 
$36.16 \mathrm{~m}$ and recoverable and local recoverable area are total of 11 to 22 layers with a total thickness of 26.0 - $34.1 \mathrm{~m}$ (Jijun and Shuguang 2003, Qu et al. 2017, Yun et al. 2017). The sedimentary association is mainly lake cycles type and clips some lake subfacies, lacustrine-delta facies and peat bog facies as body. The sedimentary sequence is: shallow lake $\rightarrow$ lacustrine-delta facies $\rightarrow$ lake shore $\rightarrow$ swamp facies $\rightarrow$ peat bog facies.

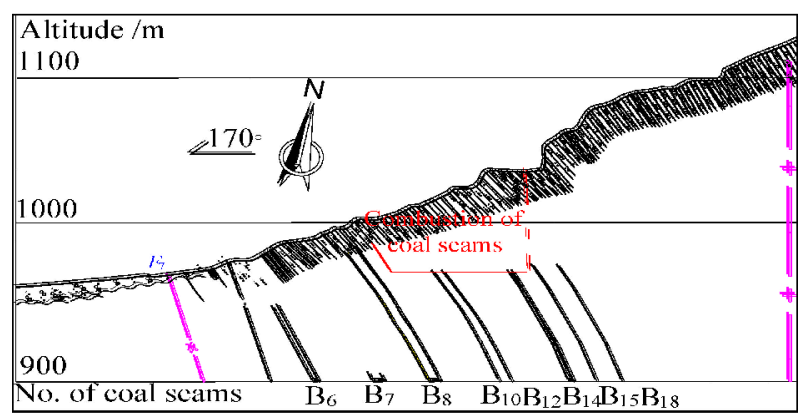

Fig. 3. Profile of mining area

The majority of coals in Xishanyao formation belong to the range of medium-extra low sulfur, part of which are high-sulfur coal (Qinping et al. 2012, Shuxun et al. 2001, Tan et al. 2017). The macrolitho type of coal focuses on semibright type and semidull type. The macrolitho components of coal are mainly clarai and fusain along with some dull coal stripe and less vitrain lineation. Microlitho-type of coal is featured by vitrinertite, clarite and micro inertial coal. The majority of inorganic maceral (mineral substance) in coal is clay and pyrite. Most of them are distributed in coal mines in banded and disseminated form. The metamorphic grade of coal is in low metamorphic bituminous stage, which are the weak reductive degree coal mainly involving as the non-caking coal and gas coal, due to the high content of inertinite which leads to the decrease of volatile yield and caking property of coal. (Yuanjiang et al. 2008, Shuguang and Jijun 2011).

\section{DISTRIBUTING CHARACTERISTIC OF HYDROGEN SULFIDE}

The hydrogen sulfide concentrate anomaly in many mine (District) of coal rock, water of well, gob and water of hotsprings (well), which are often coexist with carbon dioxide. In the 1950s', a poisoning accident was caused by $\mathrm{H}_{2} \mathrm{~S}$ in Xishan coal mine. After that, the prevention and control of $\mathrm{H}_{2} \mathrm{~S}$ in
Xishan coal mine has been carried out, which is earlier than that of the other coal mines in China (Jigang et al. 2013, Khan et al. 2017). At present, the hydrogen sulfide gas is contained in all coal seams. In the gas, the highest content of $\mathrm{H}_{2} \mathrm{~S}$ is $2.11 \%$. And the $\mathrm{H}_{2} \mathrm{~S}$ in coal seam is distributed unevenly, with the obvious distinct subdivision and zoning phenomenon. Meanwhile, $\mathrm{H}_{2} \mathrm{~S}$ is rich in the underground water in mines and goaf. The average concentration of sulfur containing compound in water is $4.19 \mathrm{mg} / \mathrm{L}$ and the sulfate is $134.38 \mathrm{mg} / \mathrm{L}$. The gas composition in coal bed mainly are $\mathrm{N}_{2}$ and $\mathrm{CH}_{4}$, with the components of $\mathrm{H}_{2} \mathrm{~S}, \mathrm{CO}_{2}, \mathrm{C}_{2} \mathrm{H}_{6}, \mathrm{C}_{3} \mathrm{H}_{8}$ and other heavy hydrocarbon. The $\delta^{13} \mathrm{C}$ value of $\mathrm{CO}_{2}$ ranges from $-18 \%$ to $-11 \%$. The distributing characteristics of $\mathrm{H}_{2} \mathrm{~S}$ are shown in Table I and Table II.

\section{TABLE I COMPONENT OF GAS IN METHANE GAS}

\begin{tabular}{lcccc}
\hline $\begin{array}{l}\text { Coal } \\
\text { seam }\end{array}$ & $\begin{array}{c}\mathrm{H}_{2} \mathrm{~S} \\
(\%)\end{array}$ & $\begin{array}{c}\mathrm{CH}_{4} \\
(\%)\end{array}$ & $\begin{array}{c}\mathrm{CO}_{2} \\
(\%)\end{array}$ & $\begin{array}{c}\mathrm{N}_{2} \\
(\%)\end{array}$ \\
\hline $\mathrm{B}_{7}$ & $0.02-1.50$ & $2.42-60.95$ & $1.09-11.29$ & $26.44-93.21$ \\
$\mathrm{~B}_{8}$ & $0.01-1.24$ & $36.06-43.25$ & $7.46-12.21$ & $39.20-50.32$ \\
$\mathrm{~B}_{12}$ & $0.003-2.11$ & $15.63-45.36$ & $2.40-10.86$ & $35.68-74.51$ \\
$\mathrm{~B}_{14}$ & $0-1.90$ & $4.88-37.64$ & $0.81-12.31$ & $49.32-94.31$ \\
$\mathrm{~B}_{15}$ & $0.006-1.07$ & $11.08-51.32$ & $5.52-6.60$ & $15.91-70.89$ \\
\hline
\end{tabular}

TABLE II. THE DRAINAGE AND PUMPING STATION AS WELL AS GAS COMPOSITION OF WINDSTONE GATE

\begin{tabular}{lcccccc}
\hline \multirow{2}{*}{$\begin{array}{l}\text { Sampling } \\
\text { location }\end{array}$} & $\mathrm{H}_{2} \mathrm{~S}$ & \multicolumn{5}{c}{ Gas composition (\%) } \\
\cline { 3 - 7 } & $(\mathrm{ppm})$ & $\mathrm{CO}_{2}$ & $\mathrm{CH}_{4}$ & $\mathrm{~N}_{2}$ & $\mathrm{C}_{2} \mathrm{H}_{6}$ & $\mathrm{C}_{3} \mathrm{H}_{8}$ \\
\hline $\begin{array}{l}\text { Pumping station } \\
\begin{array}{l}\text { Air return } \\
\text { laneway }\end{array}\end{array}$ & 74.94 & 2.287 & 11.28 & 66.72 & 0.009 & 0.0018 \\
\hline
\end{tabular}

The biggest concentration of $\mathrm{H}_{2} \mathrm{~S}$ monitored in every point of coal mine are shown in Fig. 4.

According to Fig. 4, the $\mathrm{H}_{2} \mathrm{~S}$ in coal seam is distributed unevenly. The maximum concentration of $\mathrm{H}_{2} \mathrm{~S}$ monitored in $\mathrm{B}_{14}$ digging tunnel is $63 \mathrm{ppm}$. The maximum concentration of $\mathrm{H}_{2} \mathrm{~S}$ monitored by Team One is $199 \mathrm{ppm}$. In 2011, in the process of drilling in the level of $888 \mathrm{~m}$ of wind store gate in $\mathrm{B}_{7}$ coal seam, the concentration of $\mathrm{H}_{2} \mathrm{~S}$ and methane gas as well as temperature are tested, and the outcomes are shown in Fig. 5.

According to Fig. 5, when the exploratory hole depth of No.1 reaches $5 \mathrm{~m}$, the highest concentration of $\mathrm{H}_{2} \mathrm{~S}$ is $150 \mathrm{ppm}$. When it reaches in $16-24 \mathrm{~m}$, 


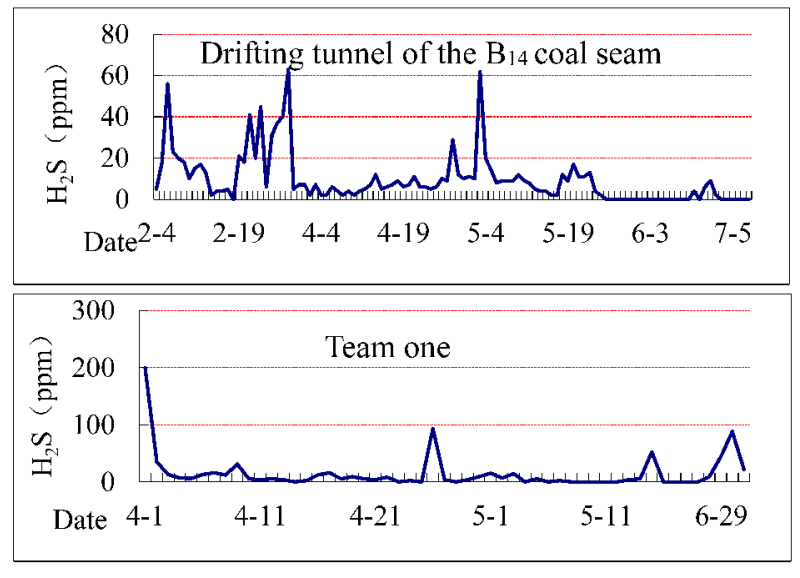

Fig. 4. Concentration of $\mathrm{H}_{2} \mathrm{~S}$ in different point

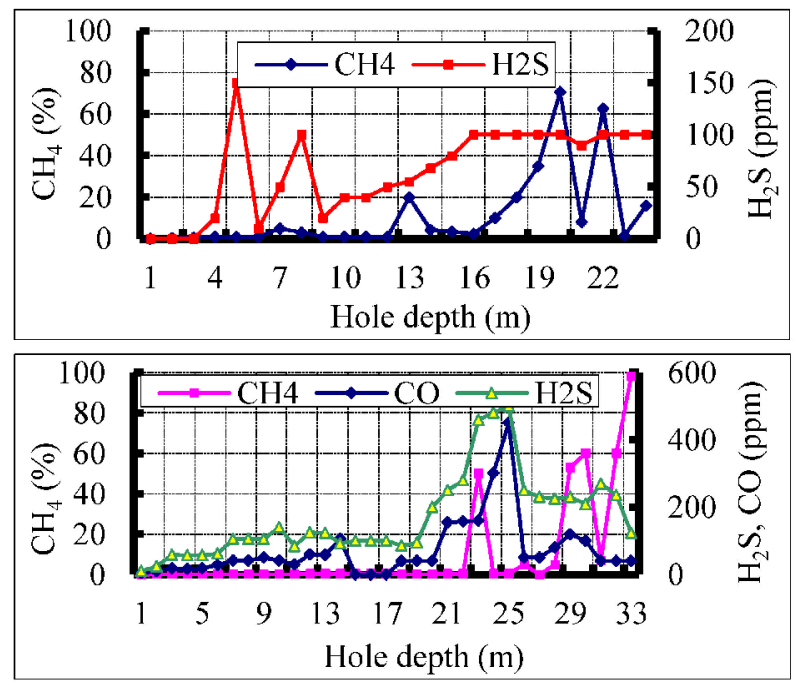

Fig. 5. Curve figure of gas composition in the exploratory hole of No.1 and No.3

the concentration of $\mathrm{H}_{2} \mathrm{~S}$ is $100 \mathrm{ppm}$, the highest concentration of $\mathrm{CH}_{4}$ is $70.5 \%$. When the exploratory hole depth reaches $24 \mathrm{~m}$, the seepage volume increases, the water temperature reaches $30{ }^{\circ} \mathrm{C}$, the concentration of $\mathrm{H}_{2} \mathrm{~S}$ in the hole rises to $899 \mathrm{ppm}$, the concentration of gas is $16 \%$. When the exploratory hole depth of No.3 reaches $3 \mathrm{~m}$, the concentration of $\mathrm{H}_{2} \mathrm{~S}$ in the hole is $12 \mathrm{ppm}$, the water temperature reaches $26^{\circ} \mathrm{C}$. When it reaches $20 \mathrm{~m}$, the concentration of $\mathrm{H}_{2} \mathrm{~S}$ rises to $105 \mathrm{ppm}$, the concentration of $\mathrm{CO}$ is $42 \mathrm{ppm}$, and then the concentration of $\mathrm{H}_{2} \mathrm{~S}$ rises sharply. When it reaches $22 \mathrm{~m}$, the seepage volume increases distinctively, the water temperature reaches $30^{\circ} \mathrm{C}$, and the concentration of $\mathrm{H}_{2} \mathrm{~S}$ rises to $380 \mathrm{ppm}$, the concentration of $\mathrm{CO}$ is $158 \mathrm{ppm}$. The maximum concentrations of $\mathrm{H}_{2} \mathrm{~S}$ and $\mathrm{CO}$ monitored are $500 \mathrm{ppm}$ and $450 \mathrm{ppm}$ respectively, and the highest volume fraction of $\mathrm{CH}_{4}$ is $98 \%$. It's obvious that the $\mathrm{H}_{2} \mathrm{~S}$ concentration in coal seam is high, that $\mathrm{H}_{2} \mathrm{~S}$ coexists with water, and that there is a similar change trend of concentration between the $\mathrm{H}_{2} \mathrm{~S}$ and $\mathrm{CO}$.

\section{CONTROL FACTORS OF ABNORMAL ENRICHMENT OF $\mathrm{H}_{2} \mathrm{~S}$}

\section{The control effect of geological structure}

This area where coal mines are located has experienced the development of multicycle structure, making its sediments distinct cyclicity, the thick sourcereservoir-seal association sedimentation formed by multicycle structure (Xiaofei et al. 2008, Ahmad et al. 2017). The foreland thrust belt structure causes the intensive compression and the development of the reverse fault. The anticline usually coexists with breakage and is incised by fault, forming the faulted anticline oil and gas reservoir, which is beneficial to the preservation of oil and gas $\left(\mathrm{H}_{2} \mathrm{~S}\right)$. Nearby the coal mines, the anticline structures such as Kalazha, the north Xiaoquzi, Xishan, coal measures and so forth, gas resources have been shown in rich. Its horizen is Jurassic, reflecting that the research area is a favorable structural trap (Shihu et al. 2007, Qinping et al. 2012, Aslam et al. 2017, Shamsudin and Majid 2017). The anticline formed by inversion of regional structure covers directly on the hollow that formed the $\mathrm{H}_{2} \mathrm{~S}$. And the breakage caused by longtime activities provids a passage for $\mathrm{H}_{2} \mathrm{~S}$ migration and capacious storage space. The main fault groups of mining area, such as Xishan fault, Wangjiagou fault and Jiujiawan fault, all belong to the late Pleistocene fault groups, being an independent structural system. Besides, most of them are thrust fault, with the characteristics of wide and gentle waves on the flat surface, the gentle fault scrap, and the small stratigraphic dip. The structures mentioned above are favorable to the preservation of $\mathrm{H}_{2} \mathrm{~S}$.

\section{The control effect of reservoir}

There are mainly three kinds of source rocks developed in study area, including Tugulu group of lower cretaceous, Badaowan formation and Xishanyao formation of middle-lower Jurassic, and middle Permian. The biggest volume of gas produced by source rocks is more than $100.0 \times 10^{8} \mathrm{~m}^{3} / \mathrm{km}^{2}$. Among them, the source rocks of middle-lower Jurassic are a kind of low mautre-mature source rock, and the organic carbon content of dark mudstone (including carbargilite) is 
$0.12-27.56 \%$ with the average value $15.51 \%$. While, organic carbon content in coal generally is 32.69 $92.25 \%$ with the average value reaching $64.49 \%$. The coal seam of Xishanyao formation where the mines are located is thick. The main type of organic parent material in coal is humus of 0 -II, and the vitrinite reflectance $\left(R_{0}\right)$ of coal is $0.5-0.7 \%$, most of which are in the low mature-mature stage. The abundant source rocks developed in the study area provide a rich material basis for the formation of $\mathrm{H}_{2} \mathrm{~S}$.

The average voidage of every coal seam in Xishan coal mine is $6.4 \%$ with moderate fracture. The average permeability is $2.56 \times 10^{-3} \mathrm{um}^{2}$. The pore structure of every coal seam belongs to the type of fracture-pore. Most of the coal seam fracture are primary structure, and the remaining fracture is the fragmentation structure. The fracture of coal seam develops well with a good openness and connectivity. Most of the fracture, which are not filled by mineral materials, increases the permeability of coal seam. The distribution of the moderate reservoir has a wide range of distribution, which provides a spacious space for the storage of $\mathrm{H}_{2} \mathrm{~S}$. The proportion of fine elastic rocks of coal seam roof in Xishan coal mine is more than $75 \%$, and that of coal seam floor is $87 \%$. The main rock property of coal seam roof and floor is fine elastic rocks, which are low-permeability isolated barrier bed and have a poor breath ability. This is favorable to the preservation of $\mathrm{H}_{2} \mathrm{~S}$ in coal seam (Jiangtao et al. 2009).

Hence, the mines have a good configuration on the space in terms of the formation, migration and concentration (preservation and storage) conditions.

\section{The control effect of hydrological characteristics}

Ground water and $\mathrm{H}_{2} \mathrm{~S}$, which are all liquid, coexist in coal-bearing rock series and surrounding rocks. Their occurrence and migration are related to pore and fracture channels in coal and rock strata. Regional surface water and underground water flow from south to north, including surface flow and underground runoff, the groundwater recharge runoff belt - Runoff overflow belt - Vertical alternating belt - horizontal runoff belt and so on. The sediments thickness of quaternary have characteristics of thickness in the south and the west, and thinness in the north and the east. Near the piedmont depth or piedmont faultsubsiding belt, the sedimentary thickness is about $400-1300 \mathrm{~m}$, with the characteristics of gradual thinner from south to north. The depressed basement is formed by the neo-tectonic movement. Its central uplift side are exposed to the surface of earth, making the distribution of phreatic water discontinuity.
In this area, a tectonic depression of the echelon faults has been developed between the uplift of first and second row as well as between the second and third row. Among them, the very thick sand gravel stratum of quaternary constitutes a relatively single and very thick water-bearing layer, providing spacious space for the storage and migration of ground water $\left(\mathrm{H}_{2} \mathrm{~S}\right)$. The water cycle features in regional basin groundwater are shown in Fig. 6.

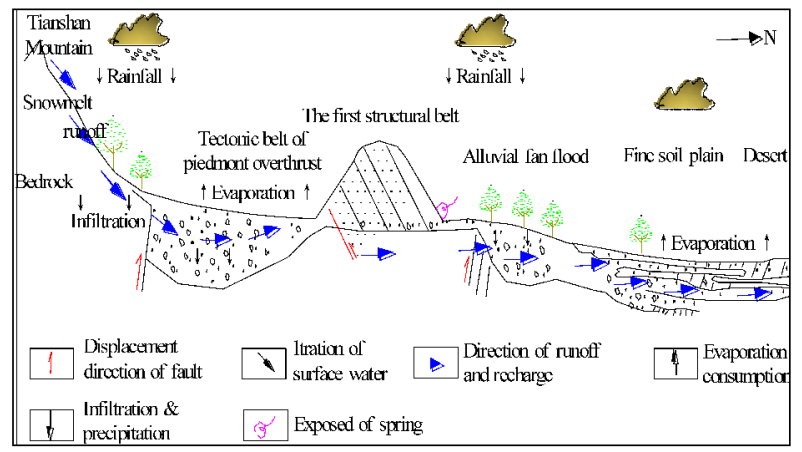

Fig. 6. Water cycle features in regional river water

The mining area is supplied by the surface water from outcrop of coal measure strata in the north Yilinheibiergen Mountain. The underground water flows from the shallowness to the deep along the layer and the steep slope. The coal reservoir is isolated by the overlying aquifer. Due to the lithostatic pressure of the deep underground aquiclude developed in upper and lower of coal bearing stratum, the movement of water and gas (methane, $\mathrm{H}_{2} \mathrm{~S}$ ) in the coal seam are prevented because of the low permeability of coal seam. Besides, the bad continuity of sand surrounding wall rock results in the slow movement of ground water in coal-bearing area. The geological structure of depression or basement uplift provides the important conditions for the enrichment of aquifer $\left(\mathrm{H}_{2} \mathrm{~S}\right)$. On the one hand, the gas flowing upward in the coal seam was blocked. On the other hand, the gas (methane, $\mathrm{H}_{2} \mathrm{~S}$ ) in the coal seam is carried by ground water migration to the deep. The function of gas controlled by the hydrodynamic leads to the enrichment of $\mathrm{H}_{2} \mathrm{~S}$, which are shown in Fig.7.

The mining area has lots of pore water and fissure water. The water-resisting loess layer in some area results in the pressure-bearing regionally in some areas of underground water, which leads to serious concentration of $\mathrm{H}_{2} \mathrm{~S}$. For example, at 24 o'clock on November 5, 2011, after the drilling and blasting 


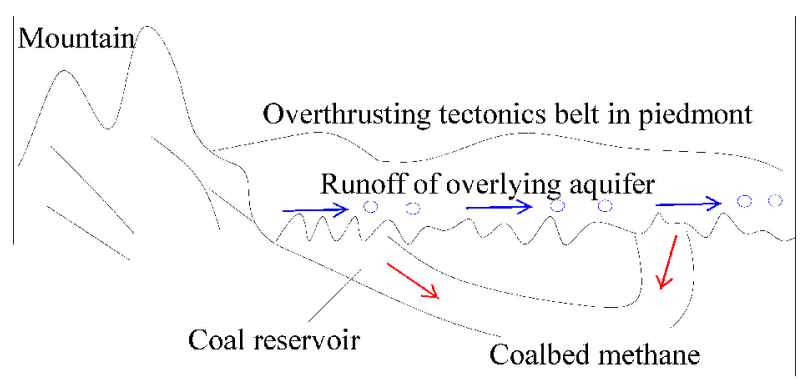

Fig. 7. Gas controlled by hydrodynamic function and the storage model of coalbed methane

in the work face of rail up the hill, a considerable amount of water and harmful gas poured out from coal seam roof of $\mathrm{B}_{19}$ and its surrounding with the concentration of $\mathrm{H}_{2} \mathrm{~S}$ as much as $400 \mathrm{ppm}$ and the concentration of gas reaching $19.5 \%$ because of the effect of shock and vibration.

The chemical properties, $\mathrm{pH}$ value, ion concentration and salinity of formation water all have an important effect on the generation and storage of $\mathrm{H}_{2} \mathrm{~S}$. The water chemical evolution characteristics of the underground water in Xishan coal mine from the south to the north are shown in Table III.

TABLE III. CHEMICAL CHARACTERISTICS OF UNDERGROUND WATER FROM SOUTH TO NORTH OF EVERY COAL MINE IN STUDY AREA

\begin{tabular}{llccc}
\hline $\begin{array}{l}\text { Mining } \\
\text { area }\end{array}$ & $\begin{array}{l}\text { Hydrochemistry } \\
\text { type }\end{array}$ & $\begin{array}{c}\text { Salinity } \\
(\mathrm{g} / \mathrm{L})\end{array}$ & $\begin{array}{c}\mathrm{H}_{2} \mathrm{~S} \\
(\mathrm{mg} / \mathrm{L})\end{array}$ & $\mathrm{pH}$ \\
\hline Daxigou & $\mathrm{SO}_{4}-\mathrm{Cl}-\mathrm{HCO}_{3}-\mathrm{Ca}$ & 1.1 & $7.89-25.32$ & 8.3 \\
Qianshuihe & $\mathrm{SO}_{4}-\mathrm{Cl}-\mathrm{Na}$ & 2.6 & $9.26-51.29$ & 8.5 \\
Liuhuanggou & $\mathrm{SO}_{4}-\mathrm{Cl}-\mathrm{K}+\mathrm{Na}$ & 3.5 & $23.89-69.45$ & 8.5 \\
Xishan & $\mathrm{Cl}_{-} \mathrm{SO}_{4}-\mathrm{K}+\mathrm{Na}$ & 6.2 & $41.89-259.63$ & 9.0 \\
\hline
\end{tabular}

(1) Along the direction of groundwater runoff of river, the chemical type of formation water changes from $\mathrm{HCO}_{3}-\mathrm{Ca}-\mathrm{Na}$ and $\mathrm{HCO}_{3}-\mathrm{SO}_{4}-\mathrm{Na}-\mathrm{Ca}$ to $\mathrm{HCO}_{3}-$ $\mathrm{SO}_{4}-\mathrm{Cl}-\mathrm{Na}-\mathrm{K}$. The content of $\mathrm{H}_{2} \mathrm{~S}$ in water body increases gradually.

(2) From Yilinheibieergen Mountain to the research area, salinity and hardness all change gradually from low to high. Salinity increases rapidly from less than $1.0 \mathrm{~g} / \mathrm{L}$ to over $6.2 \mathrm{~g} / \mathrm{L}$, and the $\mathrm{pH}$ value increases from 7.8 to 9.3 , which is an alkalescent salt water.

(3) In the regional deep confined water along the direction of underground runoff, the constant ions concentration (except bicarbonate ion) all increase, with the trend of rapid growth of the milligram equivalent present of sodium ions and potassium ions.
The calcium ion is dominant in cation and gradually gives priority to sodium ions. Although bicarbonate ion accounts for the largest proportion in anionic, there is a trend of being replaced by sulfate ion (Xiulan et al. 2015, Fang et al. 2014, Qigen et al. 2017).

The environment of deep confined water in this regional is closed well. In the reductive environment, under the effect of sulfate reducing bacteria and thermodynamic factors, $\mathrm{H}_{2} \mathrm{~S}$ is likely to come into being if it experiences the effect of Bacterial Sulfate Reduction (BSR) or Thermochemical Sulfate Reduction (TSR) (Smith and Philips 1990, Philips et al. 1990, Manzano et al. 1997, Mingju et al. 2012, Machel 2001, Cross et al. 2004, He et al. 2016, Gao et al. 2017, Li et al. 2018, Estrada et al. 2018, Ahamed et al. 2017, Poppenga and Worstell 2016). Its possible reaction formula is shown in formula (1) to formula (4).

$$
\begin{aligned}
& \sum \mathrm{CH}(\text { or } \mathrm{C})+\mathrm{SO}_{4}{ }^{2-}+\mathrm{H}_{2} \mathrm{O} \stackrel{\text { BSR }}{\longrightarrow} \mathrm{H}_{2} \mathrm{~S}+\mathrm{CO}_{2}+\mathrm{CO}_{3}^{2-} \text { (BSR) } \\
& 2 \mathrm{C}+\mathrm{CaSO}_{4}+\mathrm{H}_{2} \mathrm{O} \rightarrow \mathrm{CaCO}_{3}+\mathrm{H}_{2} \mathrm{~S} \uparrow+\mathrm{CO}_{2} \uparrow(\mathrm{TSR})
\end{aligned}
$$

$\sum \mathrm{CH}+\mathrm{CaSO}_{4} \rightarrow \mathrm{CaCO}_{3}+\mathrm{H}_{2} \mathrm{~S} \uparrow+\mathrm{CO}_{2} \uparrow(\mathrm{TSR})$

$\mathrm{C}_{\mathrm{n}} \mathrm{H}_{2 \mathrm{n}+2}$ (Heavier hydrocarbons) $+\mathrm{nSO}_{4}{ }^{2-} \stackrel{\mathrm{Mg}^{2+} \mathrm{NaCl}}{\longrightarrow}$ $\mathrm{C}_{\mathrm{n}-1} \mathrm{H}_{2 \mathrm{n}}$ (Lighter hydrocarbons) $+(\mathrm{n}-1) \mathrm{H}_{2} \mathrm{~S} \uparrow$ $+\mathrm{CO}_{2} \uparrow+\mathrm{S}+\mathrm{H}_{2} \mathrm{O}+\mathrm{CO}_{3}{ }^{2-}(\mathrm{n} \geq 2)$ (TSR)

The result is that the concentration of calcium ion decreases in formation water, and the $\mathrm{H}_{2} \mathrm{~S}$ and $\mathrm{CO}_{2}$ can come into being.

Most of the ground water in regional coal area is alkalescent salt water. While $\mathrm{H}_{2} \mathrm{~S}$ is a diprotic acid of soluble in water, the possible balance equation and ionization equilibrium equation are shown in formula (5) to formula (7).

$$
\mathrm{H}_{2} \mathrm{~S}+\mathrm{OH}^{-} \leftrightarrow \mathrm{HS}^{-}+\mathrm{H}_{2} \mathrm{O}, \mathrm{HS}^{-}+\mathrm{OH}^{-} \leftrightarrow \mathrm{S}^{2-}+\mathrm{H}_{2} \mathrm{O}
$$

$\mathrm{H}_{2} \mathrm{~S} \leftrightarrow \mathrm{H}^{+}+\mathrm{HS}^{-}, E_{1}=c\left(\mathrm{H}^{+}\right)$

$\mathrm{HS}^{-} \leftrightarrow \mathrm{H}^{+}+\mathrm{S}^{2-}, E_{2}=c^{\prime}\left(\mathrm{H}^{+}\right)$

$\mathrm{c}\left(\mathrm{S}^{2-}\right) / c\left(\mathrm{HS}^{-}\right)=1.2 \times 10^{-15}$

In above formula, the $E_{1}, E_{2}$ is an ionization equilibrium constant of $\mathrm{H}_{2} \mathrm{~S}$ and $\mathrm{HS}^{-} . c\left(\mathrm{H}^{+}\right), c\left(\mathrm{HS}^{-}\right)$is the 
concentration of $\mathrm{H}^{+}$and $\mathrm{HS}^{-}$, which is the ionization produced by $\mathrm{H}_{2} \mathrm{~S}$. $c\left(\mathrm{H}_{2} \mathrm{~S}\right)$ is the $\mathrm{H}_{2} \mathrm{~S}$ concentration of unionized. $c^{\prime}\left(\mathrm{H}^{+}\right), \mathrm{c}\left(\mathrm{S}^{2-}\right)$ is the concentration of $H^{+}$and $S^{2-}$ which is the ionization produced by $H S^{-}$. According to the formula (6) and formula (7), a relationship between molar ratio of three form sulfur with $\mathrm{pH}$ value in the aqueous solution can be drawn, which is shown in figure 8.

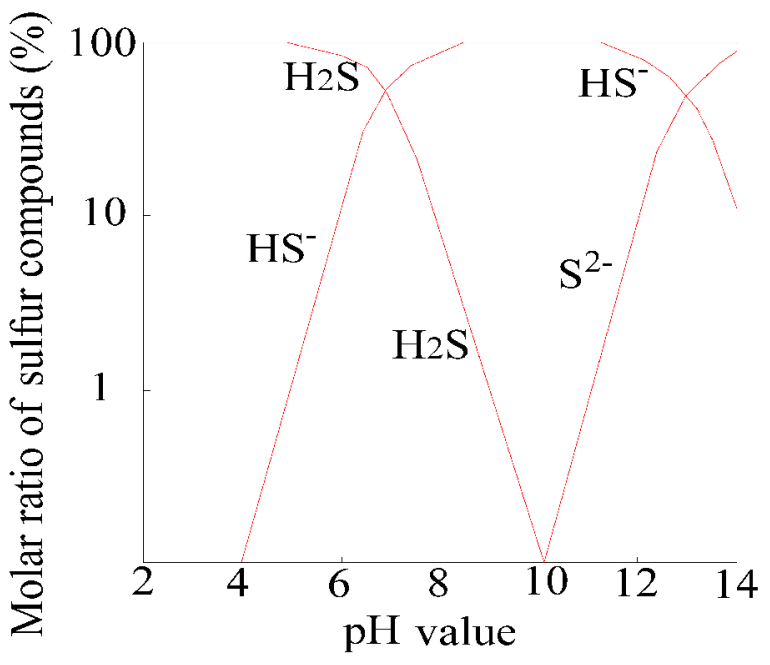

Fig. 8. Relationship between molar ratio of sulfur with $\mathrm{pH}$ value

Therefore, with the rising of sulfide content $\left(\mathrm{H}_{2} \mathrm{~S}\right)$, the concentration of $\mathrm{HS}^{-}$increases respectively, and so does the concentration of $\mathrm{OH}^{-}$with the hydrolysis of $\mathrm{HS}^{-}$. Namely, the $\mathrm{pH}$ value will rise slowly which prompts the solution of $\mathrm{H}_{2} \mathrm{~S}$, and the solution of $\mathrm{H}_{2} \mathrm{~S}$ prompts the continuous increase of content of $\mathrm{S}^{2-}$. Thereby, the formation water in this region forms a cyclic process in which the amount of sulfide content $\left(\mathrm{H}_{2} \mathrm{~S}\right)$ raises continuously and a process in which the $\mathrm{pH}$ value will rise slowly.

In the zones of fault or uplift, the formation water is blocked, and water containing considerable $\mathrm{H}_{2} \mathrm{~S}$ is exposed to the surface of the earth. The formation mode of water containing $\mathrm{H}_{2} \mathrm{~S}$ is shown in Fig. 9.

\section{CONCLUSION}

The regional structure of Xishan coal mine, located in the binding site of southern margin of Junggar basin and northern mountain Tianshan, belongs to the foothill fault-fold structural belt of southern margin of Junggar Basin. Most the coal seams which were formed by continental facies are in the range of medium-extra low sulfur and part of the coal seams belong to high sulfur coal. The content of gas and $\mathrm{H}_{2} \mathrm{~S}$ in deep coal seam are high. The hydrogen sulfide in coal seam concentrate anomaly and distribute very unevenly, which constitutes the unique feature in this area.

The special geological structure deposits some ource-reservoir-seal association sedimentation of multicycle structure, forming the gas trap which is beneficial to the reservation of $\mathrm{H}_{2} \mathrm{~S}$. The pore structure of Coal and rock strata is fracture-void, which provides huge space for the storage of $\mathrm{H}_{2} \mathrm{~S}$.

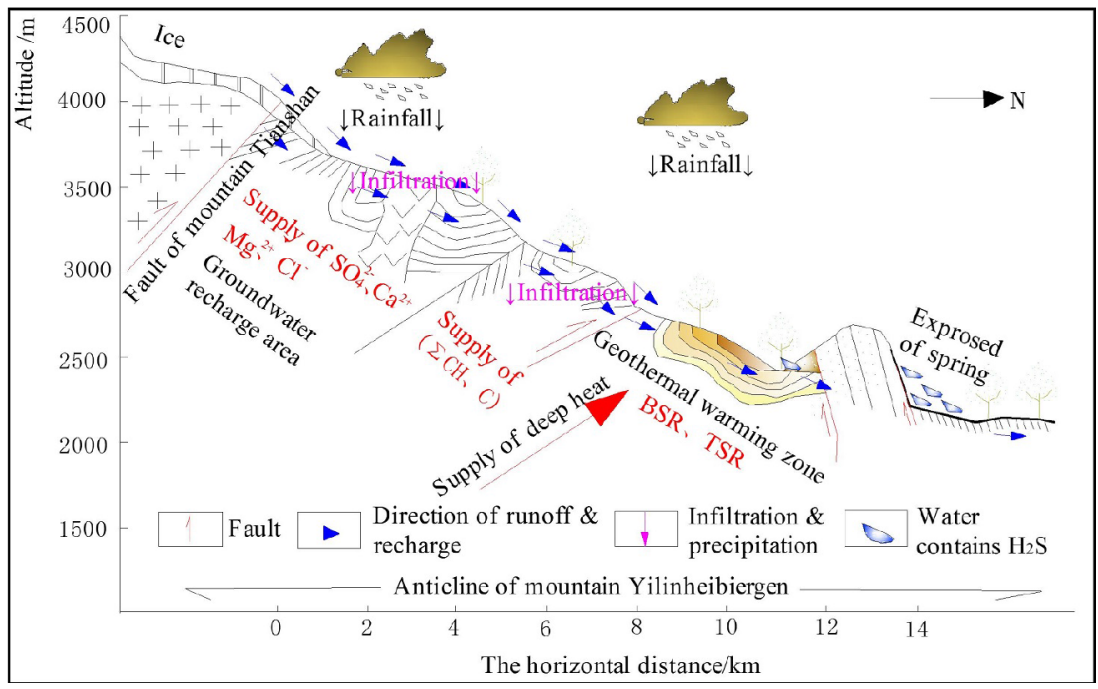

Fig. 9. Formation model of regional water contains $\mathrm{H}_{2} \mathrm{~S}$ 
The thick aquifer, formed in the sag basement as well as the sunk and sedimentary plain base, provides a huge space of occurrence and migration for groundwater and $\mathrm{H}_{2} \mathrm{~S}$ under the control of hydrodynamic block gas.

Along the runoff direction, the salinity, $\mathrm{pH}$ value and $\mathrm{H}_{2} \mathrm{~S}$ content in regional groundwater gradually increase. The environment closes well in the regional deep confined water. In sufficient organic matter and reducing environment, the hydrogen sulfide will come into being in the role of BSR or TSR.

\section{ACKNOWLEDGEMENTS}

This work was supported by "National Natural Science Foundation of China (51774116, U1504403)", "Scientific and Technological Project of Department of Science \& Technology of Henan Province (182102210320)" and "Postdoctoral Research Fund of Henan Province (2017)". In the study process, Qigen DENG is grateful to Prof. Mingju LIU of Henan Polytechnic University for his ardent guidance and help.

\section{REFERENCES}

Ahamed A.J., Loganathan K., Ananthakrishnan S., Ahmed J. and Ashraf M.A. (2017). Evaluation of Graphical and Multivariate Statistical Methods for Classification and Evaluation of Groundwater in Alathur Block, Perambalur District, India. Applied Ecology and Environmental Research, 15 (3), 105-116.

Ahmad N., Hussain T., Awan A.N., Sattar A., Arslan C., Tusief M.Q. and Mariam Z. (2017). Efficient and Eco-friendly Management of biodegradable Municipal Solid Waste (MSW) using naturally aerated Windrow Composting Technique in District Lahore Pakistan. Earth Science Pakistan. 1(1), 01-04.

Aslam S., Rahman S.U., Sabir Z. and Maqbool B. (2017). Evaluation of Cosmetics for Their Potential Contaminants and Drug Resistant Microorganisms. Acta Scientifica Malaysia. 1(2), 16-19.

Chengzao J., Guoqi W., Benliang L., cheng, X.A., and Qigui R. (2003). Tectonic evolution of two-epoch foreland basins and its control for natural gas accumulation in China's mid-western areas. Acta Petrolei Sinica, 24 (2), 3-17.

Cross M.M., Manning D.A.C., Bottrell S. and Worden R.H. (2004). Thermochemical sulfate reduction (TSR): experimental determination of reaction kinetics and implications of the observed reaction rates for petroleum reservoirs. Organic Geochemistry, 35, 393-404.
Estrada O., Lopez I.D., Hernandez A. and Ortiz J.C. (2018). Energy gap method (EGM) to increase energy efficiency in industrial processes: Successful cases in polymer processing. Journal of Cleaner Production, 176, 7-25.

DOI: 10.1016/j.jclepro.2017.12.009.

Fang F., Qi F., Zhongqin L., Wei L., Shuang J. (2014). Analysis on the hydrochemical characteristics in the upper reaches of urumqi river basin, eastern Tianshan. Journal of Natural Resources, 29 (1), 143-155.

Gao W., Baig A.Q., Ali H., Sajjad W. and Farahani M.R. (2017). Margin based ontology sparse vector learning algorithm and applied in biology science. Saudi Journal of Biological Sciences, 24 (1), 132-138.

DOI: $10.1016 /$ j.sjbs.2016.09.001.

He D.Y., Hu N.Q., Hu L., Chen L., Guo Y.P. and Chen S.S. (2016). Fault Risk Assessment of Underwater Vehicle Steering System Based on Virtual Prototyping and Monte Carlo Simulation. Polish Maritime Research, 23 (3), 97-105.

Jiangtao L., Jie L. and Jingyong Y. (2009). Seal capacity of caprock and its control effect on hydrocarbon in the foreland thrust belt of Jungar basin. Journal of Daqing Petroleum Institute, 33 (1), 12-16.

Jigang G., Xulong W. and Xiongqi P. (2013). Evaluation and hydrocarbon expulsion characteristics of the middle-lower jurassic source rock in the southern margin of Junggar basin. Journal of China University of Mining \& Technology, 42 (4), 595-605.

Jijun T. and Shuguang Y. (2003). Sequence strata and coal accumulation of lower and middle jurassic formation from southern margin of Junggar basin, Sinkiang, China. Journal of China Coal Society, 24 (2), 3-17.

Khan A., Rehman R., Rashid H. and Nasir A. (2017). Exploration of Environmental Friendly adsorbents for Treatment of Azo Dyes from Textile Wastewater and its dosage optimization. Earth Science Pakistan. 1(1), 05-07.

Li Z., Han C. and Gu T. (2018). Economics of biomass gasification: a review of the current status. Energy Sources Part B Economics Planning and Policy, 13 (2), 137-140.

Machel H.G. (2001). Bacterial and thermochemical sulfate reduction in diagenetic settings-Old and new insights. Sedimentary Geology, 140, 143-175.

Manzano B.K., Fowler M.G. and Machel H.G. (1997). The influence of thermochemical sulphate reduction on hydrocarbon composition in Nisku reservoirs Brazeau river area, Alberta, Canada Organic. Geochemistry, 27 (7/8), 507-521.

Mingju L., Qigen D. and Fajun Z. (2012). Origin of hydrogen sulfide in coal seams in China. Safety Science, 50 (4), 668-673. 
Philips R., Smith J.W. and Byrnes, R. (1990). Hydrogen Sulphide Gas Occurrence at Southern Colliery. Bowen Basin Symposium, 91-97.

Poppenga S.K. and Worstell B.B. (2016). Hydrologic Connectivity: Quantitative Assessments of HydrologicEnforced Drainage Structures in an Elevation Model. Journal of Coastal Research, (76): 90-106.

Qigen D., Mingju L. and Xuefeng C. (2017). A Study of hydrogen sulfide genesis in coal mine of southeastern margin of Junggar basin. Earth Science Frontiers, 24 (5), 395-401.

Qinping S., Bin S., Fenjin S., Qing Y., Gang C., Minfang Y. (2012). Accumulation and geological controls of low-rank coalbed methane in southeastern Junggar Basin, Geological Journal of China Universities, 18 (3), 460-464.

Qu C., Wen-Bin D. and Yun G. (2017). Russia Forest Resource Management. Malaysian Journal of Sustainable Agriculture. 1(2), 12-14.

Rafiq A., Rasheed A., Arslan C., Tallat U. and Siddique M. (2018). Estimation of greenhouse gas emissions from Muhammad wala open dumping site of Faisalabad, Pakistan. Geology, Ecology, and Landscapes. 2(1), 45-50.

Razali A., Herman H.P. and Zulkifly A.H. (2017). Noise Exposure During Orthopaedics Surgery. Science Heritage Journal. 1(2), 12-13.

Razali A., Zuraidah M.A., John B.A. and Kamaruzzaman Y. (2017). Cytotoxicity on Mcf7 Cell Lines Exposed to An Extract of The Jacalin From Jackfruit Seed. Science Heritage Journal. 1(2), 14-16.

Shamsudin S.B. and Majid A.A. (2017). Association of blood lead levels and working memory ability of primary school children surrounding ex-copper mining area in Ranau, Sabah (Malaysia). Acta Scientifica Malaysia. 1(1), 01-03.

Shihu F., Chengzao J., Yan S. and Zhaojie G. (2007). Late Cenozoic structural deformation and its implication for petroleum accumulation in the southern Junggar thrust belt. Acta Petrolei Sinica, 11, 1-5.

Shuguang Y. and Jijun T. (2011). Characteristics of CBM reservoir in eastern part of Zhunge'er basin. China coalbed methane, 8 (2), 20-23.
Shuxun S., Yong Q. and Xuehai F. (2001). Geology of coalbed methane in the continental basin-a case of Junggar and Turpan-Hami Basin. Xuzhou: China University of Mining \& Technology Press, 10-142.

Smith J.W. and Philips R. (1990). Isotopic Study of Coal Associated Hydrogen Sulphide. In Geochemistry of Sulfur in Fossil Fuels. American Chemical Society Symposium, 429 (28), 568-574.

Tan P.F., Hanafiah M.M., Mokhtar M.B. and Harun S.N. (2017). Rainwater Harvesting System: Low Awareness Level Among University Students in a High Rainfall Tropical Country. Malaysian Journal of Sustainable Agriculture. 1(2), 09-11.

Tianbao W., Dong J., Dongtao W., Yanjun W., Yiquan L. and Han Z. (2013). Mesozoic inverted structure analysis of the southern margin of the Junggar basin. Scientia Geologica Sinica, 48 (1), 176-190.

Xiaofei F., Xiaobo L., Yan S. and Shaobo, L. (2008). Caprock quality and hydrocarbon accumulation in the basins of foreland thrust belts, central and western China. Geological Review, 54 (1), 82-93.

Xinwei W., Xinwen W., Jianping L. and Yongsheng M. (2005). Analysis of the fold-thrust zone in the southern Junggar Basin, north-western China. Earth Science Frontiers, 12 (4), 411-421.

Xiulan Y., Wei F., Ruijiu W., Yuemei C., Jin Z., Chuanying H. (2015). Research on Hydrogeochemistry in Northern Plain of the Urumqi River Basin, Xinjiang. Acta Geoscientia Sinica, 36 (1), 77-84.

Yuanjiang Y., Yonghua W., Qi Y., Dameng L., Baolin H. and Wenhui H. (2008). Adsorption characteristics of low-rank coal reservoirs and coalbed methane development potential, Junggar Basin. Pet Roleum Exploration and Development, 35 (4), 410-416.

Yun G., Williams S. and Wenbin D. (2017). Water Management of the Mekong River. Malaysian Journal of Sustainable Agriculture. 1(2), 15-17.

Zhidong B., Ling L., Dongling Z., Rufeng L., Shourui G. and Yongshang K. (2005). Depositional system frameworks of the Jurassic in Junggar basin. Acta Edimentologica Sinca, 23 (2), 194-202.

Zhongxian C., Fajing C. and Zhenyuan J. (2000). Types and tectonic evolution of Junger basin. Earth Science Frontiers, 7 (4), 431-440. 